Article

\title{
Purification and Characterization of a Novel Pentadecapeptide from Protein Hydrolysates of Cyclina sinensis and Its Immunomodulatory Effects on RAW264.7 Cells
}

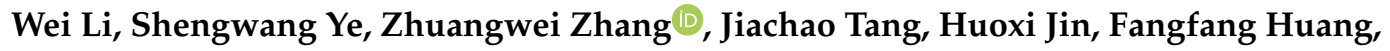 \\ Zuisu Yang, Yunping Tang *D, Yan Chen, Guofang Ding and Fangmiao Yu *(D) \\ Zhejiang Provincial Engineering Technology Research Center of Marine Biomedical Products, \\ School of Food and Pharmacy, Zhejiang Ocean University, Zhoushan 316022, China; liweizjou@163.com (W.L.); \\ yesw1003@163.com (S.Y.); all_zzw@163.com (Z.Z.); T1528358025@163.com (J.T.); jinhuoxi@163.com (H.J.); \\ gracegang@126.com (F.H.); abc1967@126.com (Z.Y.); cyancy@zjou.edu.cn (Y.C.); dinggf2007@163.com (G.D.) \\ * Correspondence: tangyunping1985@163.com (Y.T.); fmyu@zjou.edu.cn (F.Y.); \\ Tel.: +86-0580-226-0600 (F.Y.); Fax: +86-0580-818-6396 (F.Y.)
}

Received: 10 December 2018; Accepted: 1 January 2019; Published: 6 January 2019

check for updates

\begin{abstract}
In the present study, peptide fractions of Cyclina sinensis hydrolysates, with molecular weight $(\mathrm{MW})<3 \mathrm{kDa}$ and highest relative proliferation rate of murine macrophage cell line RAW 264.7, were purified by a series of chromatographic purification methods, to obtain peptide fractions with immunomodulatory activity. The amino acid sequence of the peptide was identified to be Arg-Val-Ala-Pro-Glu-Glu-His-Pro-Val-Glu-Gly-Arg-Tyr-Leu-Val (RVAPEEHPVEGRYLV) with MW of $1750.81 \mathrm{Da}$, and the novel pentadecapeptide (named SCSP) was synthesized for subsequent immunomodulatory activity experiments. Results showed the SCSP enhanced macrophage phagocytosis, increased productions of nitric oxide (NO), tumor necrosis factor- $\alpha$ (TNF- $\alpha$ ), interleukin-6 (IL-6), and interleukin-1 $\beta$ (IL-1 $\beta$ ), and up-regulated the protein level of inducible nitric oxide synthase (iNOS), nuclear factor $\kappa \mathrm{B}(\mathrm{NF}-\mathrm{kB})$, and NOD-like receptor protein 3 (NLRP3) in RAW 264.7 cells. Furthermore, the expression of inhibitor of nuclear factor $\kappa$ B- $\alpha(\operatorname{IkB}-\alpha)$ was down-regulated. These findings suggest that SCSP might stimulate macrophage activities by activating the NF- $\mathrm{KB}$ signaling pathway and can be used as a potential immunomodulatory agent in functional food or medicine.
\end{abstract}

Keywords: Cyclina sinensis; protein hydrolysates; immunomodulatory peptides; RAW264.7 cell

\section{Introduction}

The immune system plays a crucial role in maintaining human health by identifying and killing pathogens, aging cells, and tumor cells. Its functions can be affected by many factors, including social pressure, negative emotion, unhealthy lifestyle, and presence of pathogens [1]. Macrophages are vital immune cells that participate in both non-specific (innate immunity) and specific defense (cellular immunity) in vertebrates. Activated macrophages have been reported to directly kill and eliminate pathogens, necrotic cell fragments, and foreign substances via phagocytosis, and indirectly participate in immune regulation through the secretion and release of pro-inflammatory cytokines (TNF- $\alpha$, IL-6, and IL-1 $\beta$ ) and inflammatory molecules (reactive oxygen species (ROS), NO) [2] Macrophage activation is considered a promising strategy for enhancing host immune function. Currently, several drugs such as levamisole, imiquimod, pidotimod, tilorone, and cyclosporine are being clinically used for regulating human immune function. However, most immunomodulating drugs synthesized 
microbially or chemically, exhibit toxicity and side effects, which limits their usage in the prevention and treatment of chronic diseases [3]. Dietary therapy is considered an effective strategy for regulating immune function, as naturally derived immunomodulatory peptides do not show side effects.

Bioactive peptides (consisting of 2-20 amino acids) are protein fragments released from protein molecules via enzymatic hydrolysis and a series of refining processes, which harbor multiple bioactivities, including immunomodulatory [4], anti-inflammatory [5], antihypertensive [6-8], anticancer [9], antioxidant [10,11], and antifatigue [12] activities. Recently, several immunomodulatory peptides have been purified and identified from protein hydrolysates of natural origin [13]. Three immunomodulating peptides, Asn-Gly-Met-Thr-Tyr, Asn-Gly-Leu-Ala-Pro, and Trp-Thr, isolated from enzymatic hydrolysates of Alaska Pollock frame enhanced lymphocyte proliferation [14]. $\mathrm{Wu}$, et al. [15] isolated a novel hexapeptide (Glu-Cys-Phe-Ser-Thr-Ala) from wheat germ globulin, which showed significant immunomodulatory effects on RAW 264.7 macrophages. However, few immunomodulatory peptides have been purified from proteins of crustaceans and mollusks.

Cyclina sinensis, a marine bivalve mollusk, widely cultured along the mud-sandy coasts of China, has been used for treatment of asthma, dental ulcers, and inflammation in Chinese traditional medicine [16,17]. Furthermore, Cyclina sinensis is rich in protein and polysaccharides [17], which may contribute to its biological properties, such as anti-cancer, immunomodulatory, antioxidant, and hepatoprotective activities [18-21]. Zhang, et al. [22] observed that Cyclina sinensis flesh extracts stimulated immune response and enhanced body resistance by increasing the activity of acid-naphthyl acetate esterase (ANAE) in macrophages and lymphocytes in aged mice. Yu, et al. [23] isolated a novel anti-proliferative pentapeptide (Ile-Leu-Tyr-Met-Pro) from protein hydrolysates of Cyclina sinensis, which induced apoptosis of DU-145 prostate cancer cells. The Cyclina sinensis -derived angiotensin-I converting enzyme (ACE) inhibitory peptide WPMGF (Trp-Pro-Met-Gly-Phe, 636.75 Da) shows potent ACE inhibitory activity with relatively stable physiological activity under different temperatures, $\mathrm{pH}$, and simulated gastrointestinal digestion [8].

Previously, we have shown that pepsin hydrolysates of Cyclina sinensis with $\mathrm{MW}<3 \mathrm{kDa}$ significantly promoted the proliferation of RAW 264.7 murine macrophages [21]. However, the amino acid sequence of the immunomodulatory peptide was not confirmed, nor was its immunomodulatory effect accurately evaluated. Therefore, in this study, the protein hydrolysates of Cyclina sinensis with $\mathrm{MW}<3 \mathrm{kDa}$ were purified using chromatographic methods, and the amino acid sequence of the immunomodulatory peptide was identified using Edman degradation and electrospray ionization (ESI) mass analyses. The immunomodulatory activity on RAW 264.7 murine macrophages was evaluated for determining its capacity for phagocytosis, secretion of NO, TNF- $\alpha$, IL- $1 \beta$, and IL- 6 was assayed, and the protein levels of iNOS, I $\mathrm{B}-\alpha, \mathrm{NF}-\kappa \mathrm{B}$, and NLRP3 were determined using western blotting. Our results indicated that SCSP can be potentially used as an immunotherapeutic adjuvant in functional food or medicine.

\section{Results and Discussion}

\subsection{Purification of Activity Peptide}

DEAE Sepharose Fast Flow is a weak anion exchanger, and fractions with positive charges are eluted first when the hydrolysates are bonded to the exchangers [24]. Kong et al. [25] reported that higher content of positively charged peptides effectively stimulates immunomodulatory activity and is positive correlations. The ion-exchange chromatogram is shown in Figure 1a. The cell proliferative properties of the four fractions (IEC-I, IEC-II, IEC-III, and IEC-IV) obtained from the fraction with $\mathrm{MW}<3 \mathrm{kDa}$ based on its charge properties were determined at concentrations of $100 \mu \mathrm{g} / \mathrm{mL}$. The relative proliferative rate of IEC-I $(90.9 \pm 3.8 \%)$ was twice of that IEC-II $(35.2 \pm 4.0 \%)$, IEC-III $(36.6 \pm 3.5 \%)$, and IEC-IV $(44.4 \pm 2.3 \%)$ towards RAW 264.7 cells (Figure 1b). Thus, peak IEC-I was selected for further purification using Gel-25 filtration chromatography. 
Gel filtration (size exclusion) chromatography excludes high MW fractions from cross-linked agarose, which are first eluted and separated. The low MW fraction enters the interior and is subsequently separated [26]. IEC-I was fractioned into three subfractions of GFC-I, GFC-II, and GFC-III (Figure 1c) by the Sephadex G-25 gel filtration column and cell proliferative rates were determined at concentrations of $100 \mu \mathrm{g} / \mathrm{mL}$. GFC-II possessed higher cell proliferative rate $(98.9 \pm 2.7 \%)$ toward RAW 264.7 cells than GFC-I (60.8 $\pm 0.3 \%)$ and GFC-III (37.1 $\pm 1.7 \%)$ (Figure 1d). A previous study also confirmed that immune cell proliferation correlated with the MW of peptides [25].
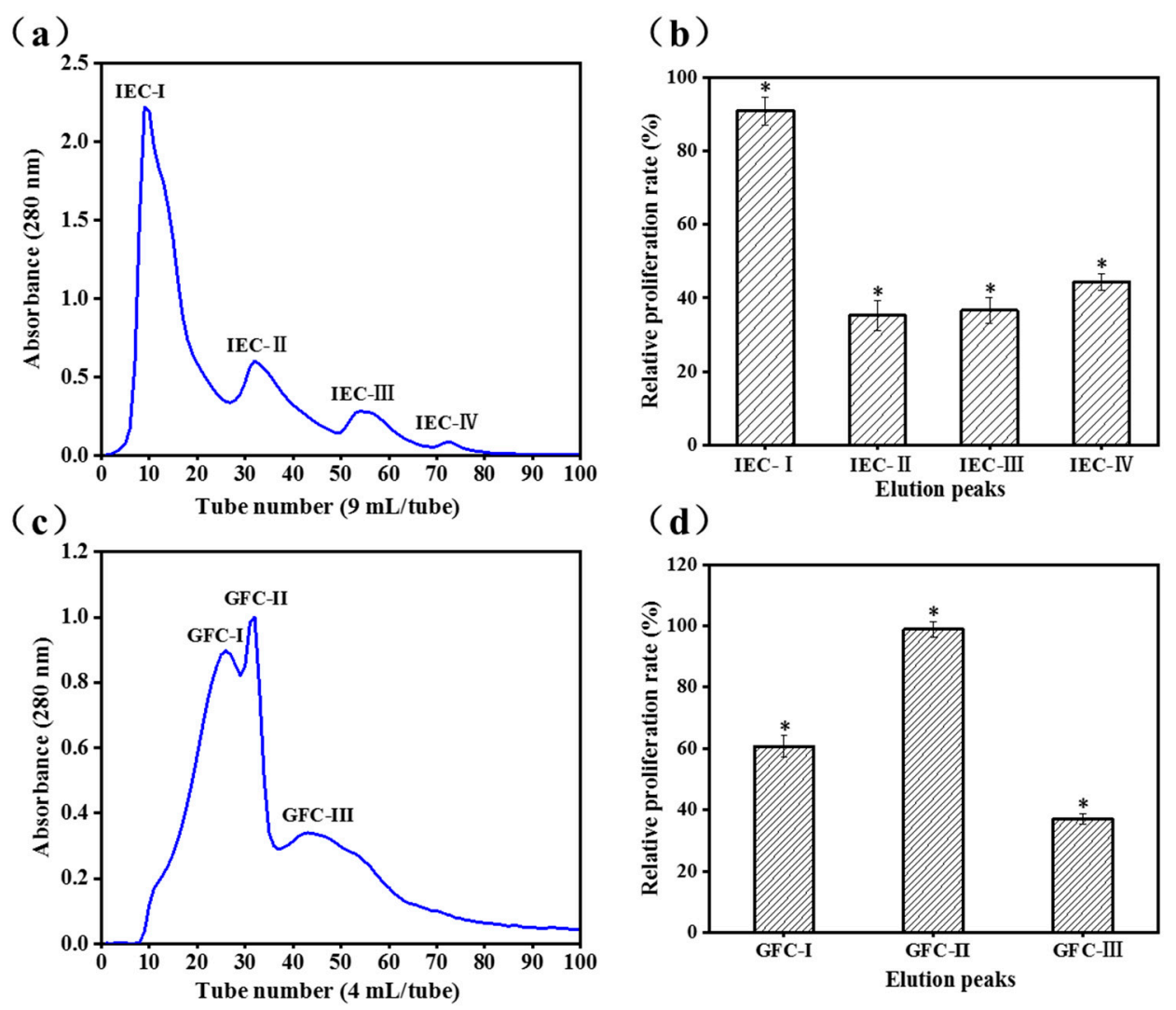

Figure 1. The peptide fraction of the Cyclina sinensis hydrolysate with $\mathrm{MW}<3 \mathrm{kDa}$ were purified using IEC and GFC; (a) Elution profiles of the fraction with $\mathrm{MW}<3 \mathrm{kDa}$ by anion exchange chromatography; (b) Effects of the elution fractions of IEC on the viability of RAW 264.7 cells; (c) Elution profiles of IEC-I by Gel filtration chromatography; (d) Effects of the elution fractions of GFC on the viability of RAW 264.7 cells; Data are presented as the mean \pm SD $(n=3) .\left({ }^{*}\right)$ Results are significantly different from the control $(P<0.05)$.

The GFC-II fraction was further purified in an RP-HPLC system, the elution profile of which is shown in Figure 2a. Fractions HPLC-I, HPLC-II, and HPLC-IV were separately collected and lyophilized for measurement of cell proliferation rate. Owing to the low content of HPLC-III and HPLC-V, minor fractions from small peaks were not collected. Fraction HPLC-IV $(98.16 \pm 2.9 \%)$ not only possessed higher immunomodulatory activity, but also higher content than HPLC-I (38.2 $\pm 1.5 \%)$ and HPLC-II $(33.4 \pm 2.1 \%)$ (Figure $2 \mathrm{~b}$ ). Thus, HPLC-IV was collected for purity testing and determination of amino acid sequences 
(a)

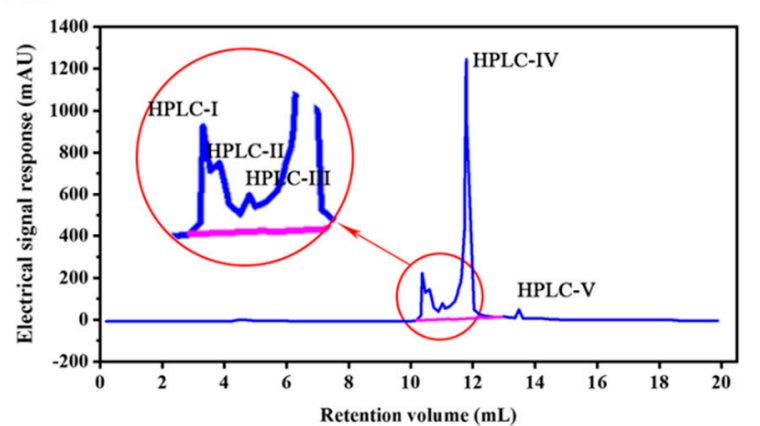

(b)

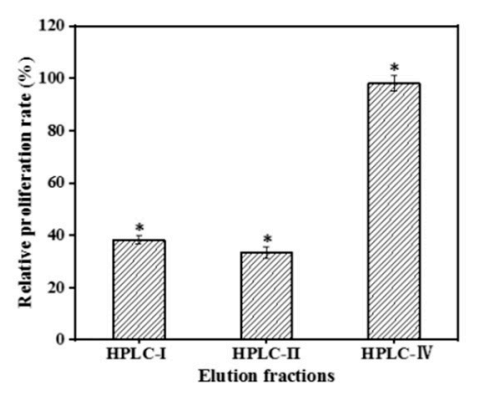

Figure 2. Purification of fractions GFC-II using RP-HPLC; (a) Elution profiles of GFC-II by Reverse phase high-performance liquid chromatography; (b) Effects of the elution fractions of RP-HPLC on the viability of RAW 264.7 cells; Data are presented as the mean \pm SD $(n=3)$. $\left.{ }^{*}\right)$ Results are significantly different from the control $(P<0.05)$.

\subsection{Analysis of Peptide Purity and Peptide Sequencing}

Only one peak was obtained in the elution profile of the HPLC-IV fraction during purity analysis (Figure 3), which was collected, lyophilized, and named CSP. The amino acid sequence of the purified peptide CSP was determined to be Arg-Val-Ala-Pro-Glu-Glu- His-Pro-Val-Glu-Gly-Arg-Tyr-Leu-Val (RVAPEEHPVEGRYLV) with a MW of $1750.78 \mathrm{Da}([\mathrm{M}-\mathrm{H}]-$, Figure 4), which was consistent with a theoretical mass of $1750.96 \mathrm{Da}$. Hydrophobicity is an important physical property of proteins. Some studies have demonstrated that hydrophobic values can effectively contribute to the immunomodulatory activity of peptides $[27,28]$. This may be due to an increase in the interaction of the peptide and cell membrane, which improves immune regulation [29]. In addition, a terminal rich in basic or hydrophobic amino acids can also be considered as an indicator of immunomodulatory activity $[15,29,30]$. In this novel pentadecapeptide, the carboxy (-Arg-Tyr-Leu-Val) and amino termini (Arg-Val-Ala-Pro-) have basic and hydrophobic amino acids, respectively, and these characteristics may contribute to immunomodulatory activity.

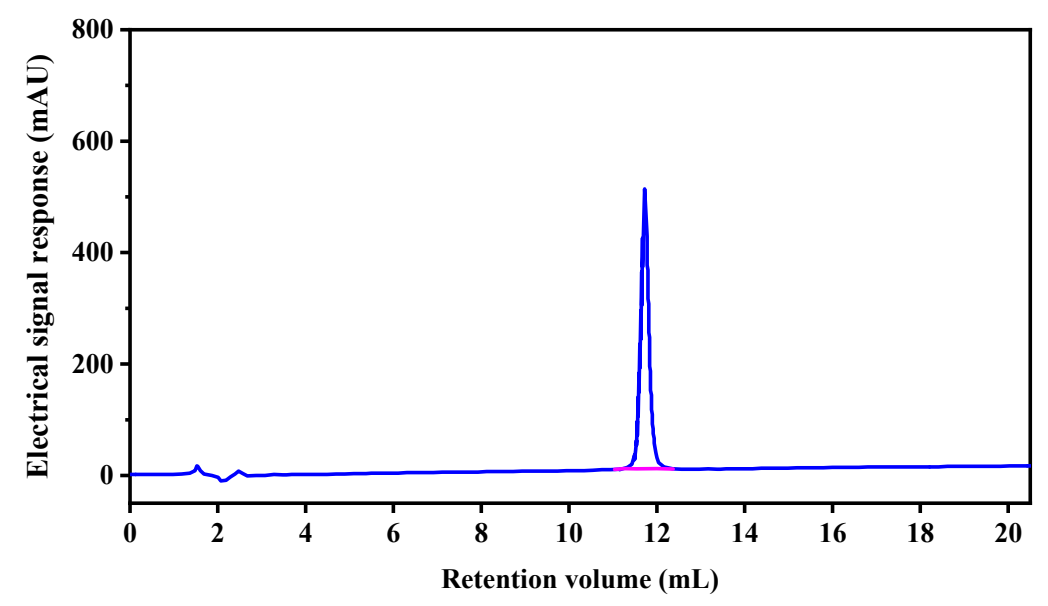

Figure 3. Purity analyze of HPLC-IV fraction by RP-HPLC. 


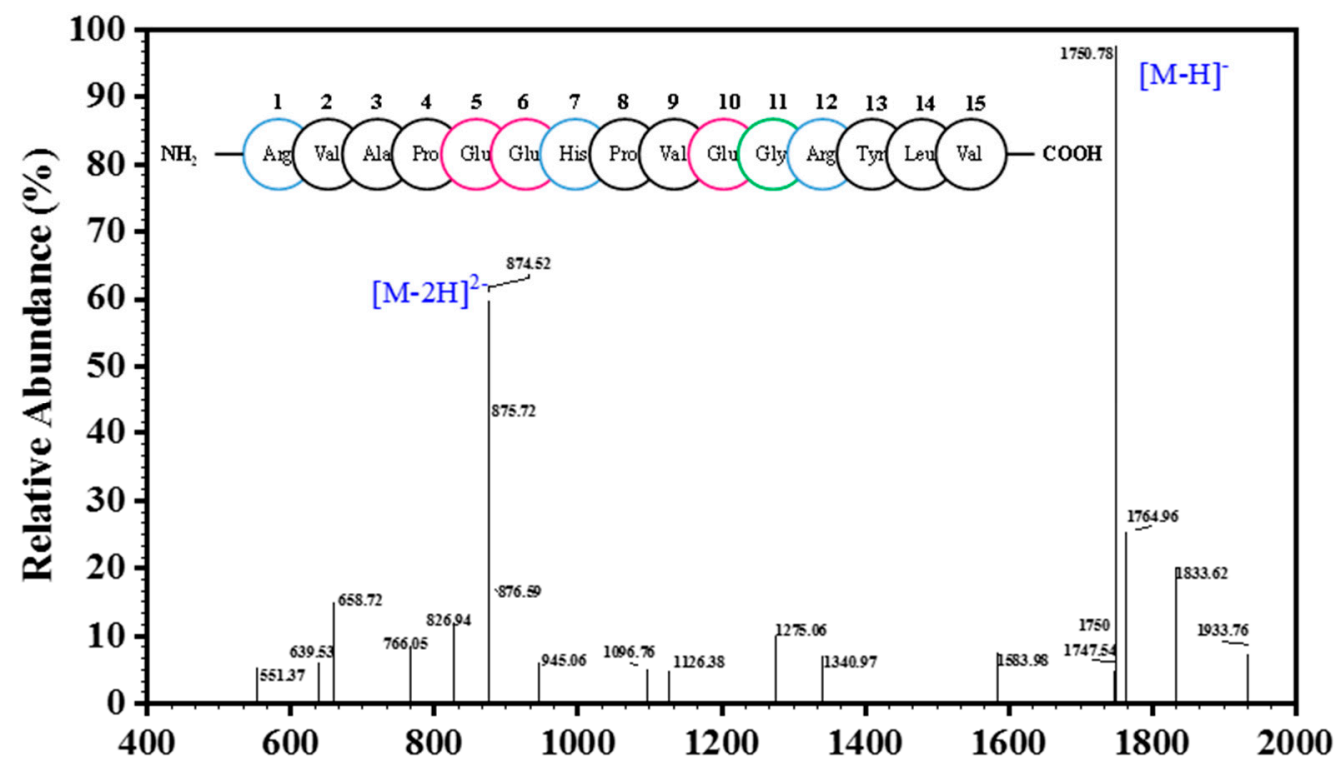

Figure 4. ESI-MS spectrum of the peptide CSP; The circles of different colors in the figure represent the amino acid sequence of CSP, wherein blue represents basic amino acid, black represents hydrophobic amino acid, red represents acidic amino acid, and hydrophilic amino acids are represented by green.

\subsection{Immunomodulatory Effects of SCSP}

\subsubsection{Effect of SCSP on Macrophage Viability}

Activated macrophages play critical roles in cell-mediated and humoral immunity. They first remove necrotic debris from tissues and cells at the site of injury via phagocytosis and then produce NO to directly kill the pathogen. Various cytokines and enzymes are secreted simultaneously, which participate in the inflammatory reaction and guide the process of body repair [31]. Therefore, macrophage viability can be used as an indicator of immunomodulatory effects and toxicity of an immune activator. The toxic effects on RAW 264.7 cells were examined using the MTT viability assay prior to investigating the immunomodulatory activity of SCSP. The results of the MTT assay (Figure 5) showed that SCSP treatment of promoted RAW 264.7 cell proliferation to a certain degree, indicating that the macrophages were activated. Compared to the control, $6.25-50 \mu \mathrm{g} / \mathrm{mL}$ SCSP significantly increased the viability of macrophages in a dose-dependent manner $(P<0.05)$. The relative proliferation activity of the cells showed a slight decrease when the concentration of SCSP was $\geq 100 \mu \mathrm{g} / \mathrm{mL}$, indicating that high concentrations of SCSP showed slight cytotoxic effect on RAW 264.7 cells. The cytotoxicity exhibited by high concentrations of immunomodulators has also been reported [32,33]. Therefore, we treated RAW 264.7 cells with $12.5-50 \mu \mathrm{g} / \mathrm{mL}$ SCSP during subsequent experiments. 


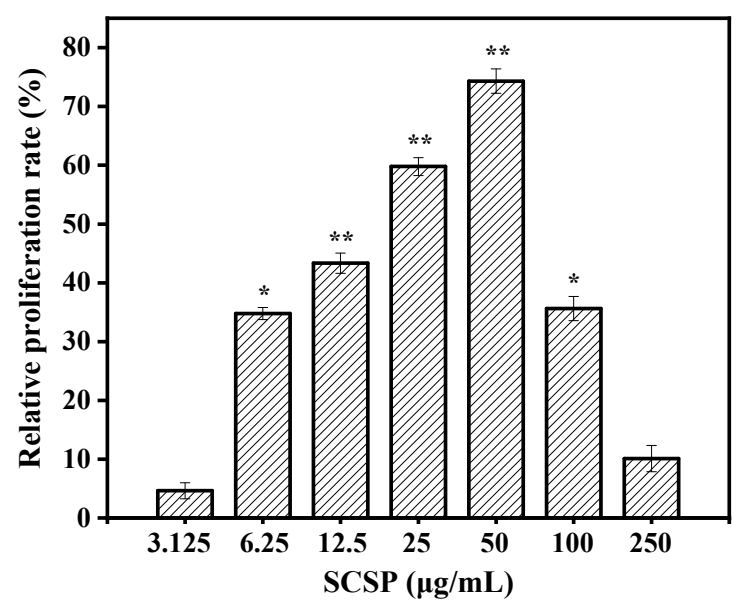

Figure 5. Effect of SCSP on macrophages viability. The significance of the subsequent data were presented as $(*)$. Results are significantly different from the control $(P<0.05)$. $\left({ }^{* *}\right)$ Results are significantly different from the control $(P<0.01)$.

\subsubsection{Effect of SCSP on Phagocytosis}

Phagocytosis is important for specific and non-specific immunity, clearance of senescent or apoptotic cells and necrotic tissue fragments, and processes related to host defense and autoimmunity [34]. One of the most striking features of activated macrophages is the uptake of exogenous particles via phagocytosis [35]. Therefore, in the present study, we determined the effect of SCSP on the phagocytic activity of RAW 264.7 cells by constructing a model of neutral red dye internalization by macrophages. As shown in Figure 6, all phagocytosis indices of SCSP exceeded 1.0 and increased in a dose-dependent manner at various concentrations. The phagocytosis index reached 2.20 at the SCSP concentration of $50 \mu \mathrm{g} / \mathrm{mL}$, which was slightly lower than that induced by $1 \mu \mathrm{g} / \mathrm{mL}$ LPS (2.32). In a previous study, Huang et al. [36] observed that oviductus ranae hydrolysate prepared with a neutral protease significantly regulated macrophage phagocytosis in a dose-dependent manner, and similar phagocytic activity was also observed in wheat germ globulin [15], Alaska pollock frame [37], and oyster (Crassostrea gigas) hydrolysates [3]. These data indicate that SCSP was able to enhance the phagocytic activity of macrophages in a dose-dependent manner.

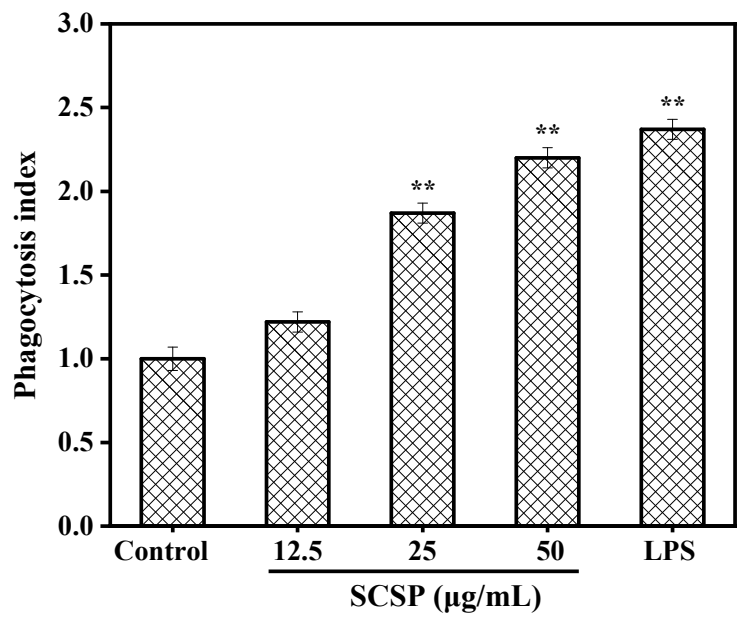

Figure 6. Effect of SCSP on phagocytic activity. The significance of the subsequent data were presented as $(* *)$. Results are significantly different from the control $(P<0.01)$.

\subsubsection{Effect of SCSP on NO Production and iNOS Expression}

$\mathrm{NO}$ acts as a key messenger molecule for activated macrophages and plays an important role in immune regulation. It not only protects against exogenous pathogens and tumor cells, but also 
regulates cellular activities associated with the immune system [38]. Mammalian NO synthase (NOS) has three different isoforms: neuronal (nNOS), inducible (iNOS), and endothelial (eNOS). iNOS is easily induced and expressed in activated macrophages and is the most important enzyme in NO synthesis $[39,40]$. Hence, we assessed macrophage activation by measuring NO secretion in SCSP-treated macrophages. The protein level of iNOS was also analyzed using western bloting. As shown in Figure 7a, SCSP stimulated NO production in RAW 264.7 cells in a dose-dependent manner. At low concentrations $(25 \mu \mathrm{g} / \mathrm{mL})$, SCSP did not significantly affect NO production. However, NO production was significantly stimulated in RAW 264.7 cells at both medium $(50 \mu \mathrm{g} / \mathrm{mL}, P<0.05)$ and high doses $(100 \mu \mathrm{g} / \mathrm{mL}, P<0.01)$. In addition, the protein levels of iNOS increased remarkably after SCSP treatment $(P<0.05)$ (Figure $7 \mathrm{~b})$. These results demonstrated that SCSP up-regulated the protein levels of iNOS and NO secretion in RAW 264.7 cells in a dose-dependent manner, which is consistent with that previously demonstrated for oviductus ranae [36], yellow field pea seeds [41] and Coix glutelin protein hydrolysates $(\leq 3 \mathrm{kDa})[42]$.

(a)

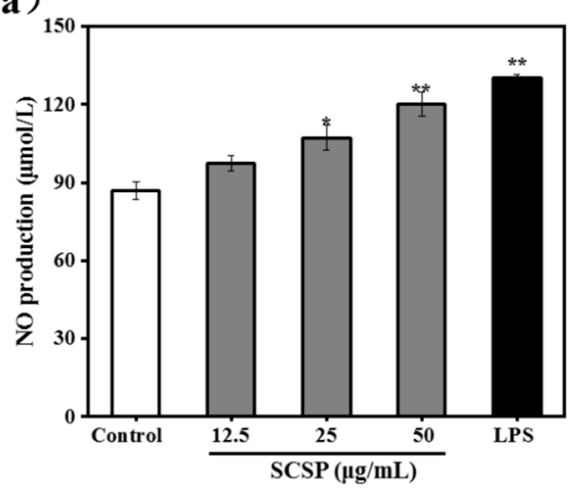

(c)

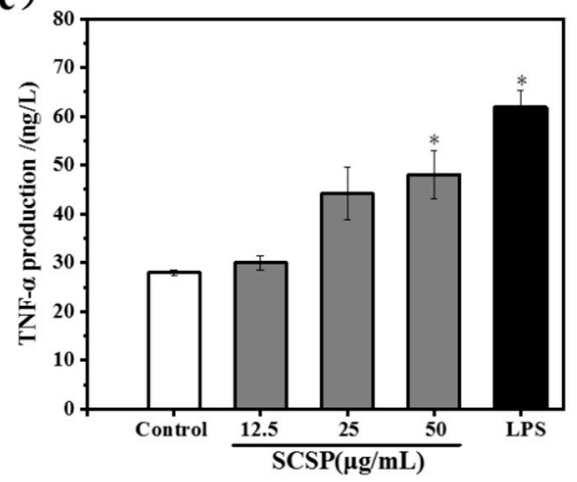

(b)

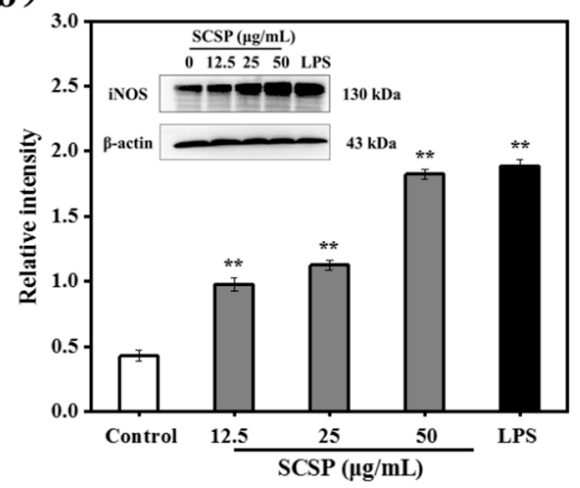

(d)

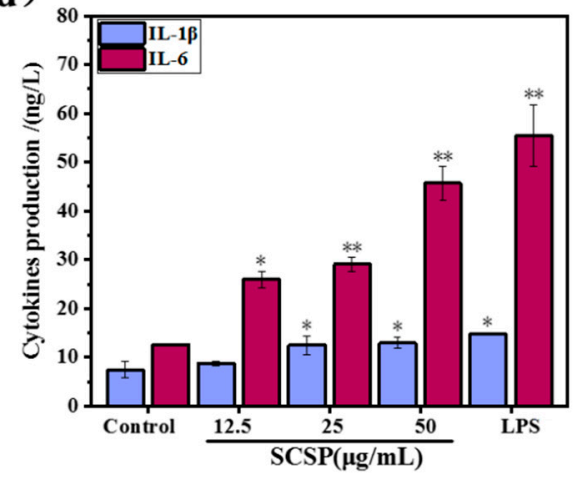

Figure 7. Assessment of release of nitric oxide and cytokines by macrophages with SCSP-treated; (a) Effect of SCSP on NO production; (b) Effect of SCSP on iNOS expression; (c) Effect of SCSP on TNF- $\alpha$ secretion; (d) Effect of SCSP on IL-1 $\beta$ and IL- 6 secretion. The significance of the subsequent data were presented as $\left(^{*}\right)$. Results are significantly different from the control $(P<0.05)$. $\left.{ }^{* *}\right)$ Results are significantly different from the control $(P<0.01)$.

\subsubsection{Effect of SCSP on TNF- $\alpha$, IL-1 $\beta$ and IL-6 Levels}

Macrophage activation is one of the most important steps in anti-infection inflammatory responses and immune responses. Activated macrophages directly kill and eliminate pathogens and foreign substances via phagocytosis when stimulated by invasion or damaged by exogenous pathogens. Subsequently, iNOS is induced and NO is released, whereas pro-inflammatory cytokines and inflammatory molecules such as peptide growth factor (PGF), interleukin (IL), tumor necrosis factor (TNF), platelet-derived growth factor (PDG), and NO are secreted during immune response [43]. Considering the important role of cytokines in mediating and modulating immune and inflammatory responses, we assessed the immunomodulatory effects of SCSP by determining the secretion of TNF- $\alpha$, 
IL-1 $\beta$, and IL- 6 by RAW 264.7 cells. The release of TNF- $\alpha$ was promoted in SCSP-treated RAW 264.7 cells in a dose-dependent manner, with significant increase in TNF- $\alpha$ level at $100 \mu \mathrm{g} / \mathrm{mL}$ SCSP (Figure 7c). Furthermore, IL-6 and IL-1 $\beta$ secretion was significantly enhanced by SCSP-treatment (Figure 7d). Previous studies on innate immune modulators have emphasized the effects of heteropolysaccharides isolated from Smilax glabra Roxb [44], polysaccharide ASKP-1 purified from Artemisia sphaerocephala Krasch seed [45], and the immunomodulatory protein PEP 1b from Pleurotus eryngii [46] on macrophage activation and secretion of IL-6, TNF- $\alpha$, and IL-1 $\beta$. These results indicated that SCSP displays significant immunomodulatory activities as it increases the secretion of NO, IL-6, IL-1 $\beta$, and TNF- $\alpha$ in RAW 264.7 cells.

\subsubsection{Effect of SCSP on NF- $\mathrm{KB}$ and NLRP3}

NF- $\mathrm{KB}$ is an indispensable transcription factor that regulates inflammatory gene expression and immune system function, and plays a vital role in inflammatory and immune responses [47]. IкB is an important member of the NF- $\mathrm{KB}$ signaling pathway and is responsible for regulating NF- $\mathrm{kB}$ activation

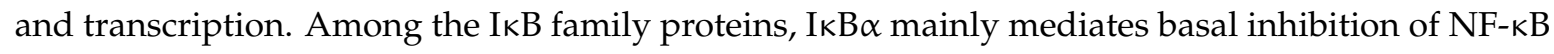
activity [48]. The NF- $k B$ dimer binds to the inhibitory protein $I \kappa B \alpha$, which sequesters the dimer in the cytoplasm in an inactive state in resting cells. However, when various stimulating factors (such as LPS, viral protein, oxygen free radicals, pro-inflammatory cytokines) stimulate cells, the cascade signal rapidly activates IкB kinase (IKK). Activated IKK phosphorylates Ser-32 and Ser-36 of IkB. Phosphorylated IKB- $\alpha$ is ubiquitinated by ubiquitin conjugation enzyme and is subsequently degraded by the proteasome, releasing NF- $\mathrm{kB}$. Activated NF- $\mathrm{kB}$ enters the nucleus and regulates transcription of genes involved in immunity and inflammation (such as iNOS, TNF- $\alpha$, IL-1 $\beta$, and IL-6). As shown in Figure $8 \mathrm{~b}$, the NF- $\mathrm{kB} / \beta$-actin ratio dramatically increased from $0.365 \pm 0.04$ (control group) to $1.669 \pm 0.08(P<0.05)$ after treatment with $50 \mu \mathrm{g} / \mathrm{mL}$ SCSP, whereas that of I $\mathrm{KB}-\alpha$ displayed an opposite trend in a dose-dependent manner (Figure 8a). This is because the cytoplasmic NF- $\mathrm{kB}$ translocated to the nucleus after degradation of IKB $\alpha$ post SCSP stimulation.

NLRP3 is the most widely studied intracellular receptor in the NOD-like receptor family [49]. Upon receipt of the induction signal, the apoptosis-associated speck-like protein (ASC), pro-caspase-1, and NLRP3 assemble into the NLRP3 inflammasome. The NLRP3 inflammasome activates caspase-1, which converts the pro-inflammatory cytokines pro-IL-1 $\beta$ and pro-IL-18 into IL-1 $\beta$ and IL-18, resulting in their secretion [49,50]. To investigate the effect of SCSP on NLRP3 inflammasome activation, we treated cells with LPS and 12.5, 25, and $50 \mu \mathrm{g} / \mathrm{mL}$ SCSP and determined the protein level of NLRP3 $(P<0.05)$. Our results illustrated that $50 \mu \mathrm{g} / \mathrm{mL}$ SCSP significantly promoted the expression of NLRP3, similar to that observed for LPS-treated RAW 264.7 cells $(P<0.05)$. SCSP induced the expression of NLRP3 in a dose-dependent manner. This is also evident from the increase in the levels of IL-1 $\beta$ in the supernatant obtained after SCSP treatment (Figure $8 \mathrm{~d}$ ). Therefore, we propose that SCSP elevated the production of NO, TNF- $\alpha$, IL- $1 \beta$, and IL- 6 in activated macrophages via the NF- $\kappa B$ and NLRP3 inflammasome signaling pathways (Figure 8a). 

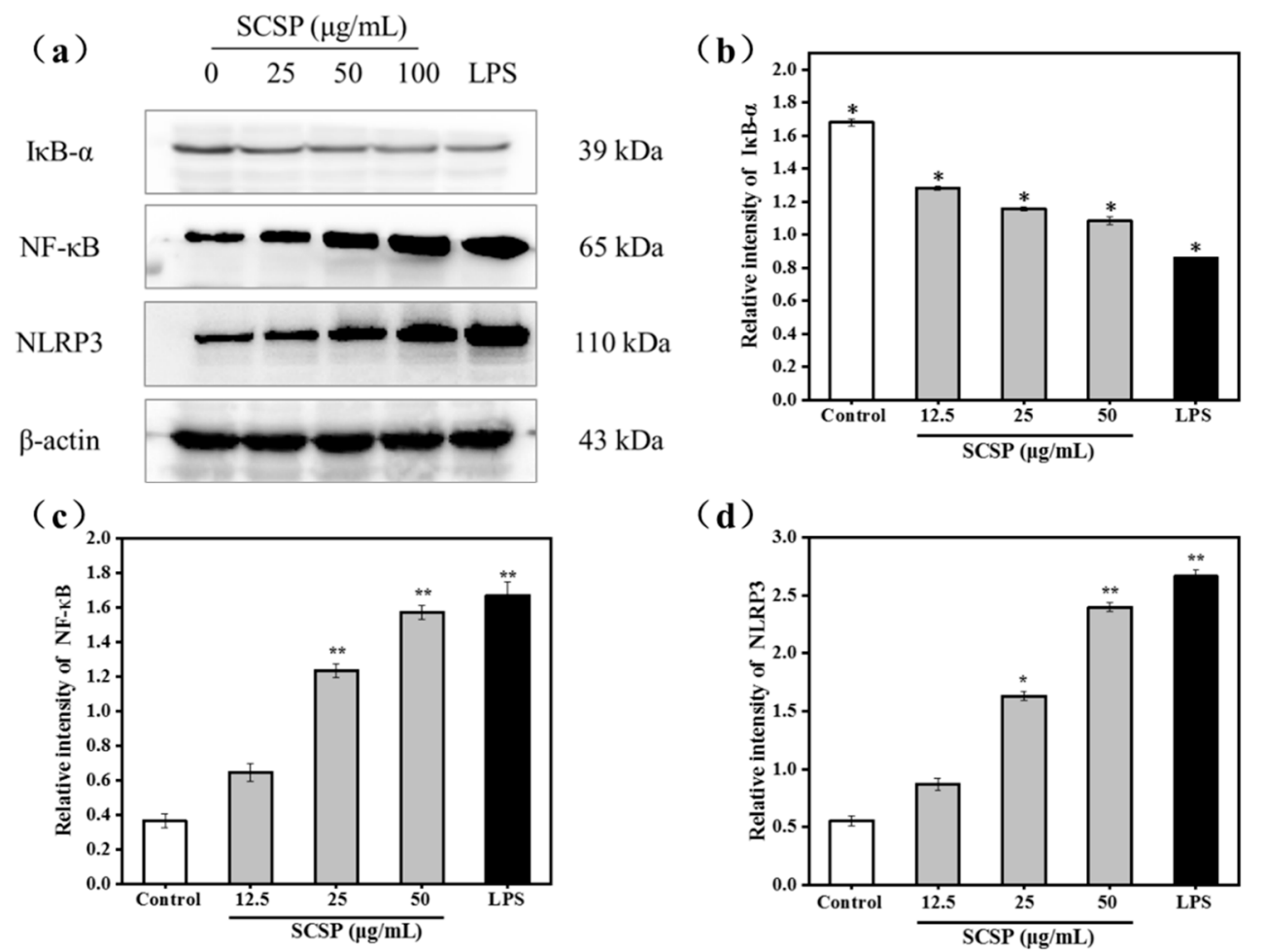

Figure 8. Effects of SCSP on the expression of IкB- $\alpha$, NF- $\kappa$ B and NLRP3; (a) Western blot analysis of I $\kappa$ B $\alpha$, NF- $\kappa B$ and NLRP3 induced by SCSP in RAW264.7 cells; (b) Effects of SCSP on the expression of I $\kappa-\alpha$ in RAW264.7 cells; (c) Effects of SCSP on the expression of NF- $\kappa$ B in RAW264.7 cells; (d) Effects of SCSP on the expression of NLRP3 in RAW264.7 cells; The intensity of specific bands was detected by the Quantity One software (version 4.62) to quantify protein expression levels; The grayscale ratio of the specific bands and $\beta$-actin were presented as the mean \pm SD $(n=3)$ by the histogram; $\left({ }^{*}\right)$ Results are significantly different from the control $\left.(P<0.05) .{ }^{* *}\right)$ Results are significantly different from the control $(P<0.01)$.

\section{Materials and Methods}

\subsection{Materials and Reagents}

Cyclina sinensis was purchased from the Laoqi market in Zhoushan China, and validated by Prof. Shenglong Zhao of Zhejiang Ocean University (Zhoushan, Zhejiang, China). Pepsin was purchased from YTHX Biotechnology Co., Ltd. (Beijing, China). Acetonitrile and trifluoroacetic acid (high-performance liquid chromatography grade) were purchased from Shanghai Weston Trading Co., Ltd. (Shanghai, China).

Dulbecco's modified Eagle medium (DMEM), fetal calf serum (FCS), and penicillin-streptomycin were purchased from Gibco BRL (Grand Island, NY, USA). Lipopolysaccharide (LPS), dimethyl sulfoxide (DMSO), and 3-(4, 5-Dimethylthiazol-2-thiazolyl)-2,5-diphenyl-2H-tetrazolium bromide (MTT) kits were purchased from Sigma-Aldrich Trading Co., Ltd. (St. Louis, MO, USA). Assay kits for IL-6, IL-1 $\beta$, TNF- $\alpha$, and NO were all obtained from Nanjing Jiancheng Bioengineering Institute (Nanjing, China). Neutral red and $N$-acetyl-L-cysteine (NAC) were purchased from Beyotime Institute of Biotechnology (Shanghai, China). Antibodies against $\beta$-actin (cat. no. 13E5), iNOS (cat. no. D6B6S), $\mathrm{I} \kappa \mathrm{B} \alpha$ (cat. no. 44D4), NF- $\mathrm{KB}$ p65 (cat. no. D14E12), and NLRP3 (cat. no. D4D8T) were obtained from Cell Signaling Technology (Boston, MA, USA). All other reagents used were of analytical grade.

\subsection{Purification of Immunomodulatory Peptide}

We prepared the protein hydrolysates of Cyclina sinensis according to the method of Ye et al. [21], and the fraction with MW $<3 \mathrm{kDa}$ was lyophilized using the alpha 1-4 LD plus freeze dryer (Marin 
Christ, Germany) for further purification. In detail, the pretreated Cyclina sinensis was treated with pepsin for $8 \mathrm{~h}$ at $42{ }^{\circ} \mathrm{C}(\mathrm{pH} 2.0$, material-liquid ratio 1:10 g/mL, enzyme dosage $1600 \mathrm{U} / \mathrm{g}$ ), and then the pepsin was inactivated in boiling water for $15 \mathrm{~min}$ and centrifuged at $12,000 \times \mathrm{g}$ for $15 \mathrm{~min}$ at $4{ }^{\circ} \mathrm{C}$, and then Cogent $\mu$ Scale TFF ultrafiltration system (Merck Millipore, Burlington, MA, USA) with MW cut-off membranes of $3 \mathrm{kDa}$ was used to separate the CSH fraction (Freeze-dried and stored at $-80{ }^{\circ} \mathrm{C}$ until use). The target immunomodulatory peptide was purified from protein hydrolysates of Cyclina sinensis via ion-exchange, gel filtration, and reverse phase high performance liquid chromatography. The relative proliferation rate of RAW264.7 cells was used as index to purify the immunomodulatory peptide.

\subsubsection{Ion-Exchange Chromatography (IEC)}

The more active fraction was dispensed into $0.05 \mathrm{M}$ Tris- $\mathrm{HCl}$ buffer, $\mathrm{pH} 7.5(2 \mathrm{~mL}, 200 \mathrm{mg} / \mathrm{mL})$, which was added to a pre-equilibrated DEAE Sepharose Fast Flow column $(7.1 \times 25 \mathrm{~cm}$, GE Healthcare Bio-Sciences $\mathrm{AB}$, Uppsala, Sweden), and stepwise eluted using ultrapure water and $\mathrm{NaCl}$ solution of different concentrations $(0.1,0.5$ and $1.0 \mathrm{M})$ at a flow rate of $6.0 \mathrm{~mL} / \mathrm{min}$. Fractions $(9 \mathrm{~mL} /$ tube) were collected and detected at $280 \mathrm{~nm}$, which were subsequently pooled and lyophilized for determining their cell proliferation activity toward RAW 264.7 cells at a concentration of $100 \mu \mathrm{g} / \mathrm{mL}$.

\subsubsection{Gel Filtration Chromatography (GFC)}

The fraction purified in the previous step ( $400 \mathrm{mg}$ ) was dissolved in $2 \mathrm{~mL}$ ultrapure water and purified using the Sephadex G-25 gel filtration column $(8.0 \times 48 \mathrm{~cm}$, GE Healthcare Bio-Sciences AB, Uppsala, Sweden), which had been equilibrated previously with ultrapure water. Ultrapure water was used as an eluent at a flow rate of $1.0 \mathrm{~mL} / \mathrm{min} ; 4 \mathrm{~mL}$ of the eluate was collected per tube and detected at $280 \mathrm{~nm}$. Three sub-fractions were collected and lyophilized for determining their cell proliferation activity toward RAW 264.7 cells at a concentration of $100 \mu \mathrm{g} / \mathrm{mL}$.

\subsubsection{Reverse Phase High Performance Liquid Chromatography (RP-HPLC)}

The fraction with highest cell proliferation activity was further purified using RP-HPLC (Agilent $1260 \mathrm{HPLC}$ with auto fraction collector system) on a ZORBAX SB-C18 $(5 \mu \mathrm{m}, 9.4 \times 250 \mathrm{~mm}$, Agilent Technologies, Santa Clara, CA, USA) column with gradient elution system based on $100 \%$ ultrapure water as solvent $\mathrm{A}$ and $100 \%$ acetonitrile as solvent $\mathrm{B}$. The gradient procedure was initiated with $100 \%$ solvent A after 3 min of holding, decreased to $30 \%$ solvent A within $5 \mathrm{~min}$, and subsequently maintained at a flow rate of $2.0 \mathrm{~mL} / \mathrm{min}$ for $10 \mathrm{~min}$. The purification was repeated more than 30 times at the same gradient elution condition and the single peak fraction was collected. N-EVAP112 nitrogen evaporator (Organomation Associates, Berlin, MA, USA) was used to separate acetonitrile from the eluent. After that, the fraction was lyophilized and their cell proliferation activity against RAW 264.7 cells and their amino acid sequences were determined.

\subsection{Determination of Amino Acid Sequence and Molecular Mass}

The immunomodulatory peptide was subjected to N-terminal amino acid sequencing on a PPSQ-31A protein sequencer (Shimadzu Corporation, Kyoto, Japan). The mass spectrometer (ZQ2000, Waters, Milford, MA, USA) combined with an ESI source was used to measure the MW of the final purified peptide. Based on the sequence results determined in the previous step, Mimotopes Biotechnology Co., Ltd. (Wuxi, Jiangsu, China) provided us with peptides synthesized using the Fmoc-solid phase method for subsequent experiments. 


\subsection{Immunomodulatory Activity Analysis in RAW264.7 Cell Line}

\subsubsection{Culture of RAW 264.7 Cells}

Murine macrophage cell line RAW 264.7 was purchased from the Chinese Academy of Sciences Cell Bank (Shanghai, China). The cells were cultured in DMEM supplemented with 10\% FCS containing $100 \mathrm{U} / \mathrm{mL}$ penicillin and $100 \mu \mathrm{g} / \mathrm{mL}$ streptomycin in an incubator with a humidified $5 \% \mathrm{CO}_{2}$ atmosphere at $37^{\circ} \mathrm{C}$.

\subsubsection{Cell Viability Assay}

The effects of SCSP on cell viability were determined using the MTT assay per the method described by Chen et al. [51]. Briefly, RAW 264.7 cells in the logarithmic growth phase were seeded in a 96-well plate $\left(1 \times 10^{4}\right.$ cells $/ \mathrm{mL}, 200 \mu \mathrm{L} /$ well $)$ and continuously cultured for $12 \mathrm{~h}$ in a $5 \% \mathrm{CO}_{2}$ incubator (Forma $3111 \mathrm{CO}_{2}$ incubator, Thermo Forma, USA) at $37^{\circ} \mathrm{C}$. Then, the medium was discarded, and the cells were treated with different concentrations of $\operatorname{SCSP}(250,100,50,25,12.5,6.25$, and $3.125 \mu \mathrm{g} / \mathrm{mL})$. LPS $(1 \mu \mathrm{g} / \mathrm{mL}$, dissolved in DMEM) and DMEM were used as the positive and control, respectively. After culturing for $36 \mathrm{~h}, 200 \mu \mathrm{L}$ MTT $(5 \mathrm{mg} / \mathrm{mL})$ was added to each well and incubated for another $4 \mathrm{~h}$, the supernatant was removed, $150 \mu \mathrm{L}$ of DMSO was added to each well, and incubated with mild agitation in the dark for $10 \mathrm{~min}$ at room temperature for complete dissolution of the produced MTT formazan crystals. The optical density $(O D)$ of each well was measured at $490 \mathrm{~nm}$ using an automatic microplate reader (SpectraMax M2, Molecular Devices, San Jose, CA, USA).

The relative proliferation rate (\%) was computed according to the following equation:

$$
\text { Relative proliferation rate }(\%)=\left[\left(O D_{\text {treated }}-O D_{\text {control }}\right) / O D_{\text {control }}\right] \times 100
$$

where $O D_{\text {treated }}$ is the $O D$ value of the cells treated with SCSP or LPS; OD $D_{\text {control }}$ is the $O D$ value of the cells cultured in DMEM without treatment.

\subsubsection{Phagocytosis of Neutral Red}

We used the method described by Ren et al. [52] with slight modifications to determine the effects of SCSP on the phagocytosis of RAW 264.7 cells. After the cells in 96-well plates were cultured with different concentrations $(100,50$, and $25 \mu \mathrm{g} / \mathrm{mL})$ of SCSP and LPS $(1 \mu \mathrm{g} / \mathrm{mL})$ for $36 \mathrm{~h}$, the cell culture medium was removed and $0.1 \%$ neutral red solution was added at $100 \mu \mathrm{L} /$ well, followed by incubation for $3 \mathrm{~h}$. The cells cultured in DMEM were used as blank group, which was untreated with SCSP or LPS. Excess neutral red in the culture solution was removed by washing twice with $0.01 \mathrm{M}$ PBS (pH 7.4), $200 \mu \mathrm{L}$ lysis solution (ethanol/acetic acid 1:1) was added per well, and the plates were shaken for $10 \mathrm{~min}$ at $25^{\circ} \mathrm{C}$. The $O D$ of each well was measured at $540 \mathrm{~nm}$ using a microplate reader.

The phagocytosis rate was calculated using the following equation:

$$
\text { Phagocytosis rate }(\%)=\left(O D_{\text {treated }} / O D_{\text {control }}\right) \times 100
$$

\subsubsection{Determination of Nitric Oxide (NO) and Cytokine Levels}

RAW 264.7 cells were seeded in 96-well plates $(1 \times 104$ cells/mL, $200 \mu \mathrm{L} /$ well $)$ and continuously cultured for $12 \mathrm{~h}$. Then, the cells were cultured with different concentrations $(100,50$, and $25 \mu \mathrm{g} / \mathrm{mL})$ of SCSP and LPS $(1 \mu \mathrm{g} / \mathrm{mL})$ for $36 \mathrm{~h}$, the supernatants were collected, and the NO level was determined using the NO assay kit (Microwell plate method, Nanjing Jiancheng Bioengineering Institute, Jiangsu, China). The amounts of secreted TNF- $\alpha$, IL-6, and IL- $1 \beta$ were determined using a microplate reader and enzyme-linked immunosorbent assay (ELISA) kits (Nanjing Jiancheng Bioengineering Institute, Jiangsu, China) according to the fabricator's instructions. 


\subsubsection{Western Blot Analysis}

We followed the methods described in Juan Du et al. [53] to measure the proteins levels of iNOS, I $\kappa \mathrm{B}-\alpha, \mathrm{NF}-\kappa \mathrm{B}$ and NLRP3 using western blotting. Total protein of the treated cells was extracted using RIPA lysis buffer, and protein concentration was measured using a bicinchoninic acid (BCA) protein quantification kit (Solarbio, Beijing, China). The proteins were separated using $12 \%$ sodium dodecyl sulfate-polyacrylamide gel electrophoresis (SDS-PAGE), transferred to a polyvinylidene fluoride (PVDF) membrane (Millipore, Billerica, MA, USA). Subsequently, the membrane was blocked with $10 \%$ non-fat milk for $1.5 \mathrm{~h}$. The PVDF membrane was incubated with diluted specific primary antibodies against iNOS, I $\kappa B-\alpha, N F-\kappa B$, and NLRP3 at $4{ }^{\circ} \mathrm{C}$ with gentle shaking overnight and washed thrice using Tris-buffered saline (TBS) plus Tween-20 (TBST). Finally, the PVDF membrane was incubated with the corresponding secondary antibody (horseradish peroxidase-conjugated goat-anti-rabbit, 1:3000) for $2 \mathrm{~h}$. The intensity of specific bands was detected using enhanced chemiluminescence (ECL) kit and quantified using the Quantity One software (version 4.62). Band intensities were normalized to that of the loading control ( $\beta$-actin).

\subsection{Statistical Analysis}

All experimental data were expressed as the mean \pm standard deviation of at least three independent experiments. Data were analyzed using one-way analysis of variance (ANOVA) of the SPSS software, version 19.0 (SPSS Inc., Chicago, IL, USA). The least significant difference (LSD) was used for post hoc multiple comparisons, and $P<0.05$ was considered statistically significant for all tests.

\section{Conclusions}

In conclusion, a novel immunomodulatory pentadecapeptide was obtained from the protein hydrolysates of Cyclina sinensis using ultrafiltration and chromatographic techniques, and its amino acid sequence was identified to be Arg-Val-Ala-Pro-Glu-Glu-His-Pro-Val-Glu-Gly-Arg-Tyr-Leu-Val (RVAPEEHPVEGRYLV) using automatic Edman degradation. Similar to most peptides with good immunomodulatory activity, the termini of the pentadecapeptide are rich in basic and hydrophobic amino acids, which may explain its immunomodulatory effects. Phagocytosis of RAW264.7 cells was significantly stimulated in a dose-dependent manner. Nitrate reductase assay and western blotting showed that SCSP increased iNOS expression and NO production. Furthermore, TNF- $\alpha$, IL-1 $\beta$, and IL-6 levels were elevated. The release of NF- $\mathrm{KB}$ from IкB- $\alpha$ was increased, consistent with the protein levels of NLRP3 after SCSP treatment. This suggested that SCSP induced macrophage activation to exert immunomodulatory effects, with the activation of the NF- $\mathrm{KB}$ and NLRP3 inflammasome signaling pathways (Figure 9). To validate the current observations, the detailed molecular mechanisms of immunomodulation and their in vivo physiological functions will be investigated in the future. Overall, our results indicated that the immunomodulatory peptide SCSP can be a good candidate for functional foods or dietary supplements. 


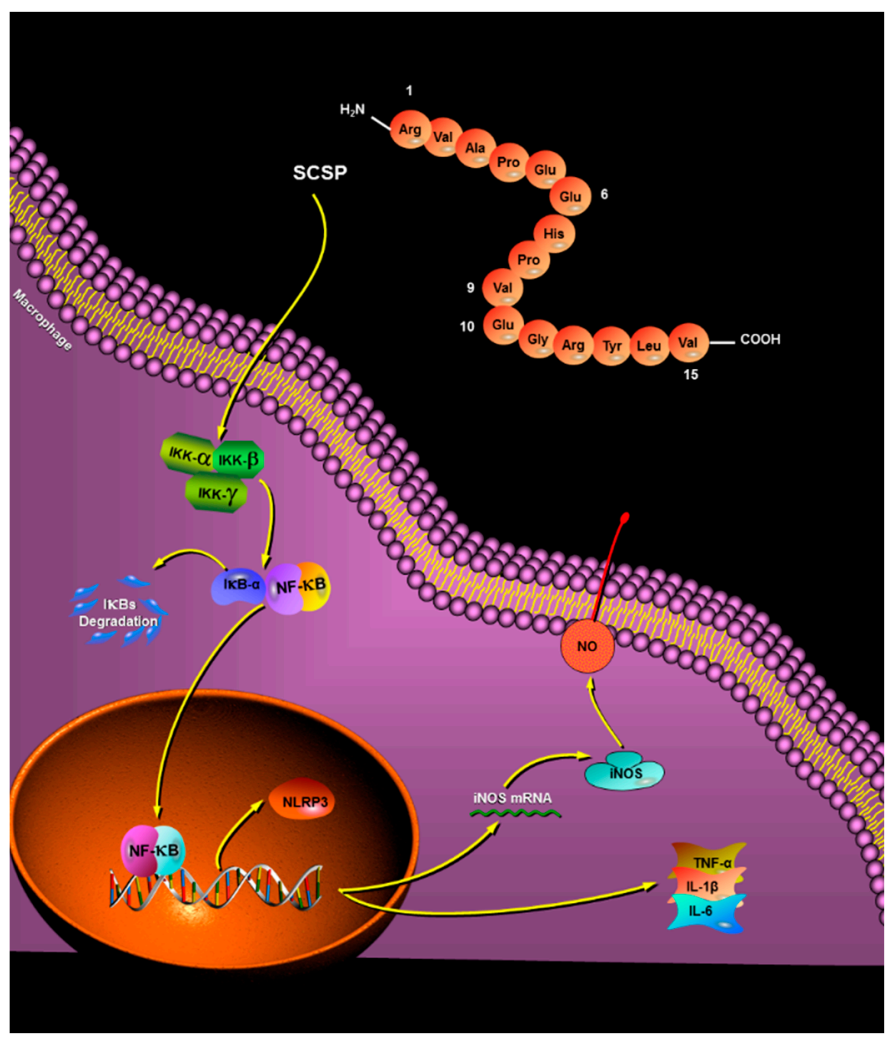

Figure 9. Possible molecular mechanisms of SCSP-induced macrophage activation.

Author Contributions: F.Y. and Y.T. conceived and designed the experiments. W.L., S.Y., Z.Z. and F.H. performed the experiments. Data analysis was conducted J.T., H.J. and Z.Y. The paper was written by Y.C., G.D. and F.Y.

Funding: This work was financially supported by the National Natural Science Foundation of China (grant No. 21502170 and No. 41806153), the Natural Science Foundation of Zhejiang Province (grant No. LQ16H300001 and No. LQ18B060004).

Conflicts of Interest: The authors declare no conflict of interest.

\section{References}

1. Chalamaiah, M.; Hemalatha, R.; Jyothirmayi, T.; Diwan, P.V.; Kumar, P.U.; Nimgulkar, C.; Kumar, B.D. Immunomodulatory effects of protein hydrolysates from rohu (Labeo rohita) egg (roe) in BALB/c mice. Food Res. Int. 2014, 62, 1054-1061. [CrossRef]

2. Ketha, K.; Gudipati, M. Purification, structural characterization of an arabinogalactan from green gram (Vigna radiata) and its role in macrophage activation. J. Funct. Foods 2018, 50, 127-136. [CrossRef]

3. Wang, Y.K.; He, H.L.; Wang, G.F.; Wu, H.; Zhou, B.C.; Chen, X.L.; Zhang, Y.Z. Oyster (Crassostrea gigas) hydrolysates produced on a plant scale have antitumor activity and immunostimulating effects in BALB/c mice. Mar. Drugs 2010, 8, 255-268. [CrossRef] [PubMed]

4. Chalamaiah, M.; Yu, W.; Wu, J. Immunomodulatory and anticancer protein hydrolysates (peptides) from food proteins: A review. Food Chem. 2017, 245, 205-222. [CrossRef] [PubMed]

5. Yu, W.; Field, C.J.; Wu, J. Purification and identification of anti-inflammatory peptides from spent hen muscle proteins hydrolysate. Food Chem. 2018, 253, 101-107. [CrossRef] [PubMed]

6. Kim, S.K.; Ngo, D.H.; Vo, T.S. Marine fish-derived bioactive peptides as potential antihypertensive agents. Adv. Food Nutr. Res. 2012, 65, 249-260.

7. Neves, A.C.; Harnedy, P.A.; O'Keeffe, M.B.; FitzGerald, R.J. Bioactive peptides from Atlantic salmon (Salmo salar) with angiotensin converting enzyme and dipeptidyl peptidase IV inhibitory, and antioxidant activities. Food Chem. 2017, 218, 396-405. [CrossRef] 
8. Yu, F.; Zhang, Z.; Luo, L.; Zhu, J.; Huang, F.; Yang, Z.; Tang, Y.; Ding, G. Identification and Molecular Docking Study of a Novel Angiotensin-I Converting Enzyme Inhibitory Peptide Derived from Enzymatic Hydrolysates of Cyclina sinensis. Mar. Drugs 2018, 16, 411. [CrossRef]

9. Huang, F.; Jing, Y.; Ding, G.; Yang, Z. Isolation and purification of novel peptides derived from Sepia ink: Effects on apoptosis of prostate cancer cell PC-3. Mol. Med. Res. 2017, 16, 4222. [CrossRef]

10. Pan, X.; Zhao, Y.Q.; Hu, F.Y.; Wang, B. Preparation and identification of antioxidant peptides from protein hydrolysate of skate (Raja porosa) cartilage. J. Funct. Foods 2016, 25, 220-230. [CrossRef]

11. Neves, A.C.; Harnedy, P.A.; O'Keeffe, M.B.; Alashi, M.A.; Aluko, R.E.; FitzGerald, R.J. Peptide identification in a salmon gelatin hydrolysate with antihypertensive, dipeptidyl peptidase IV inhibitory and antioxidant activities. Food Res. Int. 2017, 100, 112-120. [CrossRef] [PubMed]

12. Zhao, Y.Q.; Zeng, L.; Yang, Z.S.; Huang, F.F.; Ding, G.F.; Wang, B. Anti-Fatigue Effect by Peptide Fraction from Protein Hydrolysate of Croceine Croaker (Pseudosciaena crocea) Swim Bladder through Inhibiting the Oxidative Reactions including DNA Damage. Mar. Drugs 2016, 14, 221. [CrossRef] [PubMed]

13. Santiago-López, L.; Hernández-Mendoza, A.; Vallejo-Cordoba, B.; Mata-Haro, V.; González-Córdova, A.F. Food-derived immunomodulatory peptides. J. Sci. Food Agric. 2016, 96, 3631-3641. [CrossRef] [PubMed]

14. Hou, H.; Fan, Y.; Li, B.; Xue, C.; Yu, G.; Zhang, Z.; Zhao, X. Purification and identification of immunomodulating peptides from enzymatic hydrolysates of Alaska pollock frame. Food Chem. 2012, 134, 821-828. [CrossRef] [PubMed]

15. Wu, W.; Zhang, M.; Ren, Y.; Cai, X.; Yin, Z.; Zhang, X.; Min, T.; Wu, H. Characterization and Immunomodulatory Activity of a Novel Peptide, ECFSTA, from Wheat Germ Globulin. J. Agric. Food Chem. 2017, 65, 5561-5569. [CrossRef] [PubMed]

16. Chinese Animal Science Editorial Board of Chinese Academy of Sciences. Chinese Zoology, Mollusc, Bivalve, Curcuma; Science Press: Beijing, China, 2001.

17. Li, X.; Dong, Z.; Yan, B.; Cheng, H.; Meng, X.; Shen, H.; Li, J. Analysis and evaluation of nutritional components in cyclina sinensis and meretrix meretrix. Food Sci. 2010, 31, 366-370. (In Chinese)

18. Jiang, C.; Xiong, Q.; Li, S.; Zhao, X.; Zeng, X. Structural characterization, sulfation and antitumor activity of a polysaccharide fraction from Cyclina sinensis. Carbohydr. Polym. 2015, 115, 200-206. [CrossRef]

19. Jiang, C.; Xiong, Q.; Gan, D.; Jiao, Y.; Liu, J.; Ma, L.; Zeng, X. Antioxidant activity and potential hepatoprotective effect of polysaccharides from Cyclina sinensis. Carbohydr. Polym. 2013, 91, 262-268. [CrossRef]

20. Ren, Y.; Pan, H.; Yang, Y.; Pan, B.; Bu, W. Molecular cloning, characterization and functional analysis of a heat shock protein 70 gene in Cyclina sinensis. Fish Shellfish Immunol. 2016, 58, 663-668. [CrossRef]

21. Ye, S.; Yang, Z.; Li, W.; Tang, Y.; Huang, F.; Zhang, X.; Yu, F.; Ding, G. Immunomodulatory Effects of Enzymatic Peptides from Cyclina Sinensis on RAW264.7 Macrophages. Food Sci. 2018. Available online: http:/ / www.spkx.net.cn/CN/abstract/abstract44136.shtml (accessed on 4 April 2018). (In Chinese)

22. Zhang, G.; Liu, C.; Meng, Y.; Hou, Q.; Sheng, M. Quantitative study of the effects of Cyclina Sinensis flesh extract on the $\alpha$-naphthyl esterase activity of lymphocytes in the immune organs of aged rats. Chin. J. Conv. Med. 1997, 1, 38-40.

23. Yu, F.; Zhang, Y.; Ye, L.; Tang, Y.; Ding, G.; Zhang, X.; Yang, Z. A novel anti-proliferative pentapeptide (ILYMP) isolated from Cyclina sinensis protein hydrolysate induces apoptosis of DU-145 prostate cancer cells. Mol. Med. Rep. 2018, 18, 771-778. [PubMed]

24. Jarrous, N.; Altman, S. [9]—Human Ribonuclease P. In Methods in Enzymology; Nicholson, A.W., Ed.; Academic Press: Cambridge, MA, USA, 2001; Volume 342, pp. 93-100.

25. Kong, X.; Guo, M.; Hua, Y.; Cao, D.; Zhang, C. Enzymatic preparation of immunomodulating hydrolysates from soy proteins. Bioresour. Technol. 2008, 99, 8873-8879. [CrossRef] [PubMed]

26. Duong-Ly, K.C.; Gabelli, S.B. Chapter Nine-Gel Filtration Chromatography (Size Exclusion Chromatography) of Proteins. In Methods in Enzymology; Lorsch, J., Ed.; Academic Press: Cambridge, MA, USA, 2014; Volume 541, pp. 105-114.

27. Wu, W.; Zhang, M.; Sun, C.; Brennan, M.; Li, H.; Wang, G.; Lai, F.; Wu, H. Enzymatic preparation of immunomodulatory hydrolysates from defatted wheat germ (Triticum Vulgare) globulin. Int. J. Food Sci. Technol. 2016, 51, 2556-2566. [CrossRef]

28. Jacquot, A.; Gauthier, S.F.; Drouin, R.; Boutin, Y. Proliferative effects of synthetic peptides from $\beta$-lactoglobulin and $\alpha$-lactalbumin on murine splenocytes. Intl. Dairy J. 2010, 20, 514-521. [CrossRef] 
29. Mercier, A.; Gauthier, S.F.; Fliss, I. Immunomodulating effects of whey proteins and their enzymatic digests. Int. Dairy J. 2004, 14, 175-183. [CrossRef]

30. Chen, H.M.; Muramoto, K.; Yamauchi, F. Structural analysis of antioxidative peptides from soybean beta-conglycinin. J. Agric. Food Chem. 1995, 43, 574-578. [CrossRef]

31. Pixley, F.J. Tumor-Associated Macrophages. In Reference Module in Biomedical Sciences; Elsevier: Amsterdam, The Netherlands, 2018.

32. Liu, X.; Xie, J.; Jia, S.; Huang, L.; Wang, Z.; Li, C.; Xie, M. Immunomodulatory effects of an acetylated Cyclocarya paliurus polysaccharide on murine macrophages RAW264.7. Int. J. Biol. Macromol. 2017, 98, 576-581. [CrossRef]

33. Fang, Q.; Wang, J.F.; Zha, X.Q.; Cui, S.H.; Cao, L.; Luo, J.P. Immunomodulatory activity on macrophage of a purified polysaccharide extracted from Laminaria japonica. Carbohydr. Polym. 2015, 134, 66-73. [CrossRef]

34. Gordon, S. Phagocytosis: An Immunobiologic Process. Immunity 2016, 44, 463-475. [CrossRef]

35. Di, T.; Chen, G.; Sun, Y.; Ou, S.; Zeng, X.; Ye, H. Antioxidant and immunostimulating activities in vitro of sulfated polysaccharides isolated from Gracilaria rubra. J. Funct. Foods 2017, 28, 64-75. [CrossRef]

36. Huang, D.; Yang, L.; Wang, C.; Ma, S.; Cui, L.; Huang, S.; Sheng, X.; Weng, Q.; Xu, M. Immunostimulatory activity of protein hydrolysate from oviductus ranae on macrophage in vitro. Evid.-Based Complement. Altern. Med. 2014, 2014, 180234. [CrossRef] [PubMed]

37. Hou, H.; Fan, Y.; Li, B.; Xue, C.; Yu, G. Preparation of immunomodulatory hydrolysates from Alaska pollock frame. J. Sci. Food Agric. 2012, 92, 3029-3038. [CrossRef] [PubMed]

38. Coleman, J.W. Nitric oxide in immunity and inflammation. Int. Immunopharmacol. 2001, 1, 1397-1406. [CrossRef]

39. Daff, S. NO synthase: Structures and mechanisms. Nitric Oxide 2010, 23, 1-11. [CrossRef] [PubMed]

40. Fitzpatrick, B.; Mehibel, M.; Cowen, R.L.; Stratford, I.J. iNOS as a therapeutic target for treatment of human tumors. Nitric Oxide 2008, 19, 217-224. [CrossRef] [PubMed]

41. Ndiaye, F.; Vuong, T.; Duarte, J.; Aluko, R.E.; Matar, C. Anti-oxidant, anti-inflammatory and immunomodulating properties of an enzymatic protein hydrolysate from yellow field pea seeds. Eur. J. Nutr. 2012, 51, 29-37. [CrossRef] [PubMed]

42. Li, L.; Li, B.; Ji, H.; Ma, Q.; Wang, L. Immunomodulatory activity of small molecular ( $\leq 3 \mathrm{kDa})$ Coix glutelin enzymatic hydrolysate. CyTA J. Food 2017, 15, 41-48.

43. Schultze, J.L.; Schmidt, S.V. Molecular features of macrophage activation. Semin. Immunol. 2015, 27, 416-423. [CrossRef] [PubMed]

44. Wang, M.; Yang, X.B.; Zhao, J.W.; Lu, C.J.; Zhu, W. Structural characterization and macrophage immunomodulatory activity of a novel polysaccharide from Smilax glabra Roxb. Carbohydr. Polym. 2017, 156, 390-402. [CrossRef] [PubMed]

45. Ren, D.; Lin, D.; Alim, A.; Zheng, Q.; Yang, X. Chemical characterization of a novel polysaccharide ASKP-1 from Artemisia sphaerocephala Krasch seed and its macrophage activation via MAPK, PI3k/Akt and NF- $\mathrm{B}$ signaling pathways in RAW264.7 cells. Food Funct. 2017, 8, 1299-1312. [CrossRef] [PubMed]

46. Hu, Q.; Du, H.; Ma, G.; Pei, F.; Ma, N.; Yuan, B.; Nakata, P.A.; Yang, W. Purification, identification and functional characterization of an immunomodulatory protein from Pleurotus eryngii. Food Funct. 2018, 9 , 3764-3775. [CrossRef]

47. Gilmore, T.D.; Siggers, T.W.; Gerondakis, S. NF-kappaB and the Immune System. In Encyclopedia of Cell Biology; Bradshaw, R.A., Stahl, P.D., Eds.; Academic Press: Waltham, MA, USA, 2016; pp. 580-587.

48. Mizgerd, J.P. TRANSCRIPTION FACTORS।NF-kB and Ikb. In Encyclopedia of Respiratory Medicine; Laurent, G.J., Shapiro, S.D., Eds.; Academic Press: Oxford, UK, 2006; pp. 265-269.

49. Shen, H.-H.; Yang, Y.-X.; Meng, X.; Luo, X.-Y.; Li, X.-M.; Shuai, Z.-W.; Ye, D.-Q.; Pan, H.-F. NLRP3: A promising therapeutic target for autoimmune diseases. Autoimmun. Rev. 2018, 17, 694-702. [CrossRef]

50. Lee, H.; Lee, C.; Rhee, D.; Um, S.; Pyo, S. Sinigrin inhibits production of inflammatory mediators by suppressing NF-KB/MAPK pathways or NLRP3 inflammasome activation in macrophages. Int. Immunopharmacol. 2017, 45, 163-173. [CrossRef] [PubMed]

51. Chen, Y.; Ji, N.; Pan, S.; Zhang, Z.; Wang, R.; Qiu, Y.; Jin, M.; Kong, D. Roburic Acid Suppresses NO and IL-6 Production via Targeting NF-kB and MAPK Pathway in RAW264.7 Cells. Inflammation 2017, 40, 1959-1966. [CrossRef] [PubMed] 
52. Ren, Y.; Zheng, G.; You, L.; Wen, L.; Li, C.; Fu, X.; Zhou, L. Structural characterization and macrophage immunomodulatory activity of a polysaccharide isolated from Gracilaria lemaneiformis. J. Funct. Foods 2017, 33, 286-296. [CrossRef]

53. Du, J.; Li, J.; Zhu, J.; Huang, C.; Bi, S.; Song, L.; Hu, X.; Yu, R. Structural characterization and immunomodulatory activity of a novel polysaccharide from Ficus carica. Food Funct. 2018, 9, 3930-3943. [CrossRef]

(c)

(C) 2019 by the authors. Licensee MDPI, Basel, Switzerland. This article is an open access article distributed under the terms and conditions of the Creative Commons Attribution (CC BY) license (http://creativecommons.org/licenses/by/4.0/). 